\title{
STOSUNEK KOŚCIOLA KATOLICKIEGO DO ŻYDÓW W CZASIE PONTYFIKATU GRZEGORZA IX (1227-1241). ANALIZA PROBLEMU NA PODSTAWIE C. 1-19, X, V, 6
}

\begin{abstract}
The chief purpose of the article is to show the position of the Catholic Church towards Jews, as manifested in a selected fragment of Decretales of Gregory IX. Medieval canon law regulated the relations between Christian and Jews in the domains of cult and everyday life. The 19 canons which the relevant fragment comprises were assigned to three categories: laws relating to cult, laws concerning economic issues, and laws providing for the protection of Jews.
\end{abstract}

\section{Key words}

canon law, Gregory IX, Decretals, Jews, Middle Ages 
Artykuł podejmuje kwestię relacji Kościół katolicki - żydzi w czasie pontyfikatu Grzegorza IX (1227-1241). Jego zadaniem jest ukazanie wspomnianej relacji z perspektywy fragmentu Decretales (czy też Liber Extra) Grzegorza IX oznaczonego jako C. 1-19, X, V, 6. Tworzy go 19 kanonów zawartych w Titulus VI („O Żydach, Saracenach i ich sługach”) Księgi V, traktującej o przestępstwach. Fragment wymienionego dokumentu jako jedyny w całości poświęcony został kwestii innowierców, w tym zwłaszcza żydów. Zanim przejdę do omawiania wskazanego źródła, nakreślę tło, w którym kształtowały się XIII-wieczne relacje kościelno-żydowskie.

Żydzi i chrześcijanie w wiekach XI i XII skłonni byli dyskutować na temat wariantów tekstu biblijnego ${ }^{1}$. Radykalną zmianę w postrzeganiu żydów przez chrześcijan przyniosło wezwanie do wyzwolenia Ziemi Świętej z rąk niewiernych i kolejne wyprawy krzyżowe, które miały miejsce $\mathrm{w}$ latach 1096$-1291^{2}$. Z perspektywy członków Kościoła żydzi stali się niewiernymi, których należy nawracać. Poza tym pojawiła się także chęć zemsty za chrześcijan żyjących w Ziemi Świętej ${ }^{3}$. W pierwszej kolejności zemsta ta miała dotyczyć żydów, których obarczono odpowiedzialnością za śmierć Chrystusa ${ }^{4}$. Ponadto postrzeganie stylu życia żydów sprawiło, że uznano ich za „istoty czysto cielesne", co stało w opozycji wobec ascetycznego modelu życia chrześcijan ${ }^{5}$.

Postawę niechęci wzmagali w tym okresie członkowie zakonów żebraczych $^{6}$, którzy w swej duchowości kładli duży nacisk na cierpienie i śmierć

${ }^{1}$ W Hiszpanii chrześcijanie i żydzi nie tylko koegzystowali, ale także dyskutowali ze sobą na szczeblu naukowym, por. P. Johnson, Historia Żydów, Kraków 2004, s. 220; pod koniec XI w. wśród egzegetów Kościoła katolickiego wzrosło zainteresowanie hebrajską wersją Starego Testamentu na skutek m.in. rozkwitu bibliotek i kopiowania manuskryptów. Przykład postawy otwartej na wymianę myśli z wielkimi autorytetami żydowskimi dali m.in. Stefan Harding (1059-1134) i Andrzej od św. Wiktora (1110-1175), por. A. Grabois, The Hebraica Veritas and Jewish-Christian Intellectual Relations in the Twelfth Century, Medieval Academy of America 50, 4, 1975, s. 616-619, 622-623; por. też A. Saltman, Pseudo-Jerome in the Commentary of Andrew of St. Victor on Samuel, The Harvard Theological Review 67, 3, 1974, s. 195-200.

${ }^{2}$ Urban II, wzywając do wojny wyzwalającej Ziemię Świętą z rąk Turków Seldżuckich, miał użyć metaforycznego określenia niewiernych. Nazwał ich biblijnymi Medami i Persami, którzy ponownie pojawili się na tym terytorium, por. A. Grabois, The Hebraica Veritas, s. 613.

3 „Omnes siquidem illi viatores, Iudaeos, haeretios, Sarracenos acqualiter habeant exosos, quos omnes Dei appelant inimicios”, por. L. Poliakov, Historia antysemityzmu. Epoka wiary, Kraków 2008, s. 198.

${ }^{4}$ Motyw ten przewija się również $\mathrm{w}$ hymnografii religijnej średniowiecza, por. D. Flusser, Chrześcijaństwo religią żydowską. Esseńczycy a chrześcijaństwo, Warszawa 2003, s. 26-27; por. także J.H. Mundy, Europa średniowieczna 1150-1309, Warszawa 2001, s. 73.

${ }^{5}$ Por. A. Vauchez, Chrześcijanie wobec niechrześcijan, [w:] idem (red.), Ekspansja Kościoła rzymskiego 1054-1274, Warszawa 2001, s. 587.

${ }^{6} \mathrm{~W}$ tym okresie aktywni są dominikanie (zakon powstał w $1216 \mathrm{r}$.) oraz franciszkanie (zakon powstał w 1209 r.). 
Chrystusa, a w kazaniach podkreślali winę żydów ${ }^{7}$. Słowa kaznodziejów wywołały falę negatywnych reakcji na żyjącą w sąsiedztwie społeczność żydowską. Ujawniło się to bardzo w pierwszej ludowej krucjacie w 1096 r., w czasie której dokonano rzezi w Spirze, Moguncji, Kolonii, Trewirze, w Ratyzbonie Metzu, Bambergu i w Pradze ${ }^{8}$.

Proces ten L. Poliakov określa mianem „diabolizacji” społeczności żydowskiej, która przejawiała się m.in. w oskarżeniach o mordy rytualne, profanację konsekrowanych hostii ${ }^{9}$. Udział w tym mieli zarówno prości ludzie, jak i wykształceni duchowni. W wyniku tego procesu powstał obraz „teologicznego żyda", który nakładano na żydów żyjących obok ${ }^{10}$.

W czasie swego pontyfikatu Grzegorz IX angażował się w wyprawy krzyżowe oraz w proces rozszerzania Kościoła na wschód ${ }^{11}$. Jest to zatem okres Kościoła triumfującego, który w Europie posiadał realną władzę ${ }^{12}$. Świadczy o tym również fakt, że to, co zostało wypracowane w ramach prawa kanonicznego, miało wpływ na świeckie regulacje (Sachsenspiegel - 1220-1235 Schwabenspiegel - 1274-1275) ${ }^{13}$. Wyprawy krzyżowe uczyniły z papieża zwierzchnika całego chrześcijańskiego świata ${ }^{14}$.

\footnotetext{
${ }^{7}$ Por. A. Vauchez, Chrześcijanie wobec niechrześcijan, s. 587.

${ }^{8}$ Por. ibidem; L. Poliakov, Historia antysemityzmu, s. 201.

${ }^{9}$ Również papież Innocenty III (czas pontyfikatu 1198-1216) przyjmował opinię, jakoby żydzi dopuszczali się mordów rytualnych, por. A. Vauchez, Chrześcijanie wobec niechrześcijan, s. 587.

${ }^{10}$ Por. ibidem, s. 588-589.

${ }^{11}$ Por. A. Paravicini Bagliani, Kościół rzymski od Innocentego III do Grzegorza X, [w:] A. Vauchez (red.), Ekspansja Kościoła rzymskiego 1054-1274, s. 451.

${ }^{12} \mathrm{~W}$ związku z realną siłą, jaką Kościół zaczął dysponować w okresie średniowiecza, motyw zwycięstwa Kościoła nad Synagogą stał się popularny. Objawia się on w misteriach, a także w architekturze. Kościół (Ekklesia) przedstawiany jako młoda kobieta, natomiast Synagoga jako wdowa z przepaską na oczach, por. L. Poliakov, Historia antysemityzmu, s. 194; W Kaiserdom w Bambergu w południowej nawie bocznej znajdują się dwa filary, na których umocowane są dwie figury, dwa przedstawienia kobiet: Ekklesi i Synagogi (XIII w.). Ekklesia ukazana jest jako ukoronowana triumfatorka $\mathrm{z}$ kielichem i berłem zakończonym krzyżem $\mathrm{w}$ rękach ( $\mathrm{w}$ obecnym stanie wspomniana figura tych atrybutów nie posiada). Synagoga natomiast ma zawiązane oczy, co jest oznaką zaślepienia wyznawców judaizmu na naukę chrześcijańską. W prawej ręce trzyma złamane berło, z jej lewej ręki wypadają Tablice Przymierza. Poza tym, w porównaniu z postawą Ekklesi, Synagoga jest charakterystycznie wygięta, por. W. Kootz, Bamberg. Stadtführer durch die historische Altstadt mit Ausflügen in das sehenswerte Umland, Ubstadt-Weiher 2006, s. 40-41. Także w 'Abû Gôš, arabskiej wiosce oddalonej ok. $15 \mathrm{~km}$ na północny-zachód od Jerozolimy, w pokrzyżackim kościele znajduje się malowidło z XII w. przedstawiające m.in. odrzucaną postać kobiecą - personifikacja Synagogi, z której ręki wypadła bandera. Ekklesia na tym malowidle jest niewidoczna, por. E. Revel-Neher, "By Means of Colors": A Judeo-Christian Dialogue in Byzantine Iconography, [w:] R. Bonfil (red.), Jews in Byzantium. Dialectics of Minority and Majority Cultures, Leiden 2012, s. 530.

${ }^{13}$ Por. L. Poliakov, Historia antysemityzmu, s. 234.

${ }^{14}$ Por. M. Horoszewicz, Przez dwa millenia do rzymskiej Synagogi. Szkice o ewolucji postawy Kościoła katolickiego wobec Żydów i judaizmu, Warszawa 2001, s. 110.
} 
Pontyfikat Grzegorza IX wpisuje się zatem w szereg pontyfikatów papieży hegemonów. Przejął on schedę po Innocentym III. Grzegorz IX posiadał wykształcenie prawnicze i zapisał się w historii Kościoła jako twórca pierwszego zbioru prawa kanonicznego ${ }^{15}$. Treść tego prawa obejmie także sprawę relacji Kościoła do żydów, Saracenów, pogan i heretyków ${ }^{16}$.

${ }^{15}$ Grzegorz IX za pontyfikatu Innocentego III zajmował się sprawami sądowymi, por. A. Paravicini Bagliani, Kościół rzymski od Innocentego III do Grzegorza X, s. 450.

${ }^{16}$ Kwestia żydowska zajmowała Kościół nie tylko w okresie wypraw krzyżowych, ale także we wcześniejszych wiekach. Podejmowana ona była już w V i VI w. w Galii. Problem relacji chrześcijańsko-żydowskich nie skutkował ograniczeniem swobody społeczności żydowskiej, a raczej chrześcijan, którzy nie mogli spożywać wraz z żydami posiłków, nie mogli zawierać z nimi małżeństw, nie wolno im było przestrzegać przepisów szabatowych $w$ niedzielę, zakazano im mieszania się z żydami w czasie świąt wielkanocnych. Celem tych ograniczeń w ówczesnym czasie było umocnienie tożsamości chrześcijańskiej, usamodzielnienie chrześcijaństwa poprzez odcięcie się od rytów właściwych społeczności żydowskiej, a także uniemożliwienie tworzenia się herezji. Reakcja Kościoła świadczy o tym, że relacje między tymi społecznościami były bardzo dobre. Jednakże biskupi zaniepokojeni tym faktem postanowili przerwać ten "romans”. Mimo tego animozje nie uniemożliwiły wysoko postawionym chrześcijanom (też duchownym) korzystania z usług żydów, por. L. Poliakov, Historia antysemityzmu, s. 190. Wiek VI i VII naznaczone zostały próbami przymusowego nawracania żydów, por. ibidem, s. 191; w IX w. ponownie wraca głos na rzecz całkowitego odizolowania się od żydów, głównie z powodów religijnych, ponieważ znaleźli się tacy chrześcijanie, którzy zaczęli przyjmować zwyczaje żydowskie. „To w IX w. po raz pierwszy jesteśmy świadkami znaczących zmian wprowadzonych do liturgii rzymskokatolickiej, w części odnoszącej się do Żydów. O ile do tej pory w modlitwach wielkopiątkowych zwyczaj nakazywał modlić się kolejno za katechumenów, za Żydów i za pogan, w tych samych słowach i klękając po każdej modlitwie, o tyle od tej pory w mszałach widnieje napis: «pro Iudaeis non flectant» (za Żydów się nie klęka). Poprzez ten zabieg zaznaczone zostaje, że Żyd należy do odrębnej kategorii, że jest czymś innym i czymś więcej niż zwykłym «niewiernym», a skutki takiego podejścia dadzą w pełni o sobie znać kilka wieków później”, por. ibidem, s. 193-194; Pokazała to chociażby agresywna postawa ludności w czasie I wyprawy krzyżowej. W XIII w. oficjalnych wypowiedziach Stolicy Apostolskiej pojawia się temat żydów. Żydzi byli opisywani w negatywny sposób jako lud upadły i okryty hańbą. W Adhortacji Grzegorza IX skierowanej do biskupów francuskich w 1233 r. można odnaleźć następujące słowa: „Mimo, że niewierność Żydów zasługuje na potępienie, ich stosunki z chrześcijanami są użyteczne a nawet konieczne, ponieważ noszą oni w sobie obraz Zbawiciela naszego i zostali stworzeni przez Stwórcę rodzaju ludzkiego. Zgodnie z wolą Bożą nie mogą zostać wytraceni przez istoty przez Niego stworzone, niezależnie od tego, jak podłą była ich postawa; ich ojcowie byli przyjaciółmi Boga, a ich potomkowie będą zbawieni (...)”, por. ibidem, s. 397. Prawa ustalane wobec niewiernych przez Kościół mają swoją paralelę w prawach stanowionych przez muzułmanów wobec Żydów i chrześcijan, tzw. pakt Omara z VII w. Pojawiają się elementy podobne: budynki niewiernych nie mogą być wyższe od budynków muzułmanów, nie wolno niewiernym w jawny sposób prezentować swojej pobożności, chrześcijanie i żydzi mają nosić właściwe im ubrania (ubiór charakteryzuje niewiernego), por. ibidem, s. 48. Prawdopodobnie żółty znak, który mieli nosić żydzi w chrześcijańskiej Europie, ma swoje źródło właśnie w prawach stanowionych przez muzułmanów. W państwie muzułmańskim chrześcijan rozpoznawano po żółtym znaku noszonym na szacie. Taki sam kolor znaku nosiły prostytutki. Muzułmanie tym sposobem chcieli pokazać, że chrześcijanie i ich wiara nie są nic warci, por. G. Kemmether (niepubl.), por. też G. Ring, [online]. Wikipedia [dostęp: 2013-05-18]. Dostępny w Internecie: <http://de.wikipedia.org/wiki/Gelber_ Ring>. 
Grzegorz IX powołał sędziów delegowanych, którzy w imieniu papieża rozstrzygali o spawach heretyków lub podejrzanych o herezję. Ludzie ci byli rekrutowani z grona zakonników, których specjalnie przygotowywano do tego zadania ${ }^{17}$.

Innym ważnym wydarzeniem, które miało miejsce w czasie pontyfikatu Grzegorza IX, były dyskusje nad Talmudem. Jedna z głównych ról przypadła w udziale ex-żydom, gorliwie atakującym uczonych żydowskich. We franciszkańskim habicie Mikołaj Donin dyskutował o Talmudzie, pokazując, że zawiera on antychrześcijańskie passusy. Donin przedstawił Grzegorzowi IX Talmud jako dzieło „niemoralne i obraźliwe dla chrześcijan”18. W $1236 \mathrm{r}$. Grzegorz IX za namową zakonów żebraczych dokonał potępienia Talmudu ${ }^{19}$. Skierował także list do władców chrześcijańskich z prośbą o przeprowadzenie dochodzenia w celu ustalenia, czy oskarżenia rzucane w stronę Talmudu są uzasadnione. Ludwik IX, król Francji, odpowiedział, organizując w 1240 r. w Paryżu debatę ${ }^{20}$.

Przyczyną wystąpienia przeciw Talmudowi było nie tylko to, że zawierał urywki wymierzone w chrześcijan, ale też to, że zaczął on zastępować Tanach i zyskał rangę niemalże równą tekstowi biblijnemu. Zmianę nastawienia żydów do Starego Testamentu ${ }^{21}$ Kościół uznawał za rodzaj herezji ${ }^{22}$.

${ }^{17}$ Por. G. Ryś, Inkwizycja, Kraków 1998, s. 62-63; Grzegorz IX powołał inkwizycję do zwalczania herezji albigensów w 1233 r., por. A. Hastings (red.), Historia chrześcijaństwa, Warszawa 2002, s. 170. Być może powoływanie inkwizytorów z zakonu dominikańskiego wiązało się m.in. z sympatią Grzegorza IX, jaką darzył tę wspólnotę. Grzegorz, jeszcze zanim został papieżem, wspierał zakon św. Franciszka i św. Dominika, por. A. Paravicini Bagliani, Kościół rzymski od Innocentego III do Grzegorza X, s. 451.

${ }^{18}$ Por. L. Poliakov, Historia antysemityzmu, s. 218, 220.

${ }^{19}$ Por. P. Johnson, Historia Żydów, s. 218.

${ }^{20}$ Por. L. Poliakov, Historia antysemityzmu, s. 218-219; por. też R. Chazan, The Condemnation of the Talmud Reconsidered (1239-1248), Proceedings of the American Academy for Jewish Research 55, 1988, s. 11-30; Poznawanie Talmudu w kręgach uniwersyteckich przyczyniło się do większej nietolerancji żydów u chrześcijańskich scholastyków, por. J. Cohen, Scholarship and Intolerance in the Medieval Academy: The Study and Evaluation of Judaism in European Christendom, The American Historical Review 91, 3, 1986, s. 606-613; Papież Grzegorz IX obdarzył Uniwersytet Paryski przywilejami w bulli Parens Scientiarum z 13 kwietnia 1231 r., dzięki czemu instytucja ta stała się niezależna w nadawaniu tytułów naukowych, por. A.L. Gabriel, The Conflict Between the Chancellor and the University of Masters and Students at Paris During the Middle Ages, [w:] A. Zimmermann (red.), Die Auseinandersetzungen an der Pariser Universität im XIII. Jahrhundert, Berlin-New York 1976, s. 112-113.

${ }^{21}$ Termin „Stary Testament” znany jest jedynie w świecie chrześcijańskim. W tym miejscu używam go w znaczeniu, jakie nadała mu tradycja chrześcijańska. Trzeba jednak zauważyć, że żydzi nie określają tym mianem swoich świętych ksiąg.

${ }^{22}$ Por. A. Vauchez, Chrześcijanie wobec niechrześcijan, s. 586. 
Przy badaniu dokumentów pochodzących z tego okresu należy pamiętać, że stoją za nimi mentalność i retoryka zupełnie inne od współczesnych. Omawiane w tym artykule relacje są odbiciem świata średniowiecznej Europy, który kierował się porządkiem zapewnionym przez hierarchię. Hierarchia bytów chroniła przed chaosem. Każdy byt posiadał właściwe sobie miejsce, a każda społeczność umieszczona była na odpowiednim poziomie takiej drabiny. Przekroczenie granic, w których zostało się osadzonym, rozpatrywano także z perspektywy moralnej. Próba zmiany własnego statusu spotykała się z przykrymi konsekwencjami. Poza tym średniowieczny umysł chciał pojąć świat jako całość. Łączył zatem nauki w jeden harmonijny system, który służył interpretacji otoczenia ${ }^{23}$. Ten obraz świata zhierarchizowanego, gramatycznie uporządkowanego i przede wszystkim religijnego również odbija się $\mathrm{w}$ analizowanym poniżej dokumencie.

\section{DEKRETALY GRZEGORZA IX}

Omówienie Decretales Grzegorza IX składać się będzie z trzech części. W pierwszej zawarte zostaną informacje ogólne, dotyczące powstania Decretales i ich treści. W drugiej opisany będzie obraz mentalności uczonych średniowiecznych odnośnie do innowierców. Jest to konieczne, ponieważ opinie uczonych wpływały na kształt tworzącego się prawa. W części ostatniej przedstawione zostaną kanony Decretales tworzące Titulus VI, Księgi V.

${ }^{23}$ „W najbardziej charakterystycznym dla siebie wydaniu człowiek średniowiecza nie był marzycielem ani wędrowcem. Był organizatorem, kodyfikatorem, budowniczym systemów. Chciał «miejsca na wszystko i wszystkiego na właściwym miejscu». Rozróżnianie, określanie, układanie rubryk było jego rozkoszą. Choć pełen burzliwej działalności, był równie pełny impulsów, żeby je sformalizować. Wojna została ( $w$ intencjach) sformalizowana przez sztukę heraldyki i reguły rycerskie; namiętność seksualna ( $w$ intencjach) została ujęta w wypracowany kodeks miłości. Wysoce oryginalna i wzniosła filozoficzna spekulacja zacieśnia się w sztywny system dialektyczny skopiowany od Arystotelesa. Kwitną szczególnie takie studia jak prawo i teologia moralna, które wymagają uporządkowania bardzo rozmaitych szczegółów. Każdy sposób, w jaki poeta może pisać (łącznie z pewnymi sposobami, jakich raczej nie powinien używać), jest sklasyfikowany w sztuce retoryki. Niczego bardziej nie lubili ludzie średniowiecza i niczego lepiej nie robili od sortowania i porządkowania", por., C.S. Lewis, Odrzucony obraz. Wprowadzenie do literatury średniowiecznej i renesansowej, Kraków 1995, s. 21, 23; „Utrzymanie równowagi w społeczeństwie wymagało, by hierarchii i ustrukturyzowaniu przydać potrzebne narzędzie nacisku w postaci ustalonej mentalności, moralności i religii. Biada temu, kto chciałby wyjść poza swój stan! W oczach ludzi i Boga taki śmiałek popełniał jeden $\mathrm{z}$ najcięższych grzechów. Pragnienie promocji społecznej musiało być wyrzucone z trzynastowiecznej społeczności. Po naporze XI i XII wieku, wiek XIII zaistniał jako okres stabilizacji i bezruchu", por. J. Le Goff, Apogeum chrześcijaństwa: ok. 1180-ok. 1330, Warszawa 2003, s. 49. Takiemu porządkowaniu świata sprzyjał system nauczania. Sztuki wyzwolone: gramatyka, dialektyka, retoryka, arytmetyka, muzyka, geometria, astronomia charakteryzują się wysoką dyscypliną prowadzenia badań, por. C.S. Lewis, Odrzucony obraz, s. 181-182. 


\section{Ogólna charakterystyka}

Celem dokumentu wydanego pod patronatem papieża Grzegorza IX było uporządkowanie praw stanowionych w Kościele katolickim. Uporządkowanie to polegało głównie na uzgodnieniu praw zawartych w Dekrecie Gracjana z $1140 \mathrm{r}$. z prawami powstałymi po nim, ujednoliceniu ich oraz wyjaśnieniu ${ }^{24}$. Praca nad nowym zbiorem zyskała w ten sposób autorytet Stolicy Apostolskiej $^{25}$. Grzegorz IX wykonanie zbioru powierzył dominikaninowi Rajmundowi de Peñafort ${ }^{26}$.

Papież promulgował nowy zbiór praw w 1234 r. w bulli Rex pacificus. W bulli tej Grzegorz IX uzasadnił ujednolicenie praw oraz wspominał o zamieszaniu, jakie panuje $\mathrm{w}$ zbiorach praw przez rozproszenie różnych konstytucji i dekretałów, niekiedy wzajemnie sprzecznych. Poza tym niektóre z nich były zbyt rozwlekłe. Jednocześnie papież zabronił tworzenia innych kompilacji praw bez zezwolenia Stolicy Apostolskiej ${ }^{27}$. Zbiorem tym miano posługiwać się w sądach i szkołach. Stał się podstawą prowadzenia procesów sądowych, a także wykształcenia przyszłych prawników ${ }^{28}$. Nazywano go Compilatio lub Liber Extra lub też Decretales Gregorii IX.

${ }^{24}$ „Już od czasów Kościoła pierwotnego był zwyczaj zbierania świętych kanonów w jedno, aby ich znajomość, korzystanie z nich i zachowywanie stawało się łatwiejsze. (...) Rzeczywiście w ciągu pierwszych dziesięciu wieków w różnych miejscach pojawiały się prawnie niezliczone zbiory praw, sporządzone raczej prywatnym staraniem, w których zostały zawarte normy przeważnie przez sobory i papieży wydane i inne od mniejszych źródeł zaczerpnięte. W połowie XII wieku tego rodzaju złączenie zbiorów i norm, nierzadko ze sobą sprzecznych, ponownie zostały zredagowane z prywatnego pomysłu przez mnicha Gracjana w konkordię praw i zbiorów. Ta konkordia, później nazwana «Dekretem Gracjana», stanowiła pierwszą część wielkiego owego zbioru praw Kościoła, który zaczerpnąwszy przykład $\mathrm{z}$ «Corpus Iuris Civilis» cesarza Justyniana został nazwany «Corpus Iuris Canonici» i zawierał prawa, które prawie w ciągu dwu wieków przez najwyższą władzę papieży zostały ustanowione przy wsparciu biegłych w prawie kanonicznym, a nazywano ich glosatorami”, por. Codex Iuris Canonici. Auctoritate Ioannis Pauli PP. II promulgatus. Kodeks Prawa Kanonicznego. Przekład polski zatwierdzony przez Konferencję Episkopatu, Poznań 1984, s. 19.

${ }^{25}$ Por. P. Hemperek, W. Góralski, Historia źródeł i nauki prawa kanonicznego, Lublin 1995, s. $96-97$.

${ }^{26}$ Por. ibidem; o Rajmundzie i jego pracy por. K. Pennington, The Decretalists 1190-1234, [w:] W. Hartmann, K. Pennington (red.), The History of Medieval Canon Law in the Classical Period, 1140-1234. From Gratian to the Decretals of Pope Gregory IX, Washington 2008, s. 240-241. Więcej: S. Kuttner, Raymond of Peñafort as editor: The "decretales" and "constitutions" of Gregory IX, Bulletin of Medieval Canon Law 12, 1982, s. 65-80.

${ }^{27}$ Por. ibidem, s. 97.

${ }^{28}$ "The study of canon law and Roman law had become an integral part of legal studies throughout Europe, and its jurisprudence became the «Ius commune» of Europe. (...) The «Ius commune» had become a kay element of ecclesiastical learning and government", por. K. Pennington, The Decretalists 1190-1234, s. 245. 
Zbiór praw Grzegorza IX podzielony jest na pięć ksiąg o następujących nazwach: Iudex (sędzia), Iudicium (proces), Clerus (duchowieństwo), Connubium (małżeństwo), Crimen (zbrodnia). Każda księga podzielona jest kolejno na tytuły, dotyczące konkretnych zagadnień. Te następnie zbudowane są z kanonów (zwane capitula). Zbiór ten zawiera w sobie akty prawne, które nie zostały zamieszczone w Dekrecie Gracjana i powstały później oraz teksty z dzieł Ojców Kościoła ${ }^{29}$.

Niektórzy uważają, że w zawartości tego zbioru brak prawnego porządku, a poszczególne zagadnienia nie zostały wyraźnie od siebie oddzielone ${ }^{30}$. Mimo tych niedociągnięć Decretales Grzegorza IX uznaje się za pierwszą oficjalną i ogólną kolekcję prawa kanonicznego, która pozostawała w mocy aż do roku 1917, kiedy to ogłoszono Kodeks Prawa Kanonicznego ${ }^{31}$.

\section{Obraz innowiercy}

Aby zrozumieć charakter przepisów prawa kanonicznego odnoszącego się do innowierców, należy wpierw zrekonstruować obraz niewiernego, jaki funkcjonował w okresie analizowanym w niniejszym artykule ${ }^{32}$. Nacisk zostanie tu położony bardziej na Saracenów, ponieważ obraz społeczności żydowskiej zostanie zaprezentowany w dalszej części, przy omawianiu poszczególnych capitula z Dekretałów. Niemniej stosunek do Saracenów można przełożyć również na relacje z żydami, choćby dlatego, że w analizowanym źródle żydów, Saracenów i pogan ustawiono w jednej linii, tzn. nie odróżniono wyraźnie praw dotyczących żydów od praw dotyczących Saracenów ${ }^{33}$.

${ }^{29}$ Por. P. Hemperek, W. Góralski, Historia źródeł i nauki prawa kanonicznego, s. 98-99; Por. też W.M. Plöchl, Geschichte des Kirchenrechts, II: Das Kirchenrecht der abendländischen Christenheit 1055 bis 1517, Wien-München 1962, s. 477-481.

${ }^{30}$ Por. P. Hemperek, W. Góralski, Historia źródeł i nauki prawa kanonicznego, s. 99.

${ }^{31}$ Por. A. Dębiński, Church and Roman Law, Lublin 2010, s. 94, 96.

32 „Fakt istnienia wyznawców innych religii był w Europie chrześcijańskiej znany, i to nie tylko na granicy dzielącej jej mieszkańców od ludów obcych. Wśród chrześcijan mieszkali bowiem Żydzi, a w pewnych okolicach południa Europy Saraceni czy Maurowie. W interesującym nas okresie występowały także herezje, których zwolennicy różnili się od chrześcijan nie tylko w zakresie wiary, moralności i kościelnego porządku, ale z reguły występowali przeciw ustalonym zasadom i w innych zakresach życia zbiorowego. Stąd uczeni ówcześni, opierając się zresztą na przepisach obojga praw, stwierdzali istnienie innowierców, odróżniając ich z reguły wyraźnie od heretyków", por. L. Winowski, Innowiercy w poglądach uczonych zachodniego chrześcijaństwa XIII-XIV wieku, Wrocław 1985, s. 25.

33 „Stosunek Kościoła do ludzi odmiennej wiary zawsze był wrogi i represyjny. Niemniej jednak, na ile można to prześledzić w naszych zabytkach, stopień wrogości wobec różnych kategorii niewiernych był niejednakowy. Zwłaszcza stosunek do muzułmanów nie jest tak jednoznacznie negatywny, jak do heretyków. Muzułmanie - to przedstawiciele innej religii, są wrogami, prowadzi 
Wyobrażenia na temat innowierców w okresie XII-XIII w. często nie były poparte rzetelną wiedzą, a mimo tego przyjmowali je także uczeni tego okresu oraz tworzący i komentujący prawo. Wiedza na temat żydów i Saracenów była raczej ogólna, niepełna, żywiła się pogłoskami. Wpływały na nią opowieści na temat ludów pogańskich, które chrystianizował zakon krzyżacki. Stereotypy, za pomocą których opisywano żydów i Saracenów, odnoszono także do innych ludów ${ }^{34}$. Papierkiem lakmusowym, według którego można było określić bliżej daną społeczność, była w ówczesnym świecie religia. W sytuacji współżycia ludności o różnym pochodzeniu i kulturze religia stanowiła jedyny wyróżnik, „wyznaczała nieprzekraczalną granicę w każdym niemal zakresie życia zbiorowego"35. Przekonanie o prawdziwości własnej religii stanowiło kryterium podziału społeczeństwa na wiernych i niewiernych, przy czym ci drudzy w tak pojmowanym świecie równali się zagrożeniu, które należy zminimalizować.

Obraz innowiercy w dużej mierze tworzyli uczeni, którzy mieli znaczny wpływ na światopogląd tamtego okresu. Tomasz z Akwinu dzielił innowierców na trzy grupy. Pierwszą stanowili ci, którzy odrzucali wiarę bez uprzedniego poznania jej - Saraceni. Drugą grupę tworzyli ci, którzy odrzucili wiarę in figura - żydzi. Do trzeciej Tomasz zaliczał tych, którzy zaprzeczali przyjętej wierze - heretycy ${ }^{36}$. Podobny podział przyjął Rajmund de Peñafort ${ }^{37}$. Natomiast Wilhelm Ockham (uczony z późniejszego okresu) traktował Saracenów, żydów i pogan jako heretyków ${ }^{38}$.

Kanoniści i legaliści żydów i Saracenów umieszczali w jednym szeregu. Uznano ich za innowierców. Komentarze kanonistów, którymi opatrzyli przepisy prawne, opierały się na przesłankach dotyczących pochodzenia Saracenów i żydów ${ }^{39}$. W argumentacji uczonych, dotyczącej statusu społecznego innowierców, nie zabrakło odniesień do Starego Testamentu. Według Hostiensisa Saraceni etymologicznie wywodzą się od Samarytan i podobnie jak oni są bałwochwalcami. Poza tym nie uznają pism ważnych dla chrześci-

\footnotetext{
się z nimi wojny, ale ich poglądów nie omawia się w kazaniach; w ogóle stosunki z muzułmanami nie sprowadzają się jedynie do wrogości. Saracena można nawet nawrócić, możliwe są z nim także kontakty pokojowe. Na przykład sułtan Saladyn występuje w literaturze łacińskiej jako mądry władca”, por. A. Guriewicz, Kultura i społeczeństwo średniowiecznej Europy. Exempla XIII wieku, Warszawa 1997, s. 231.

${ }^{34}$ Por. L. Winowski, Innowiercy w poglądach uczonych, s. 13.

${ }^{35}$ Por. ibidem, s. 132.

${ }^{36}$ Por. ibidem, s. 27.

${ }^{37}$ Por. ibidem, s. 137.

${ }^{38}$ Por. ibidem, s. 32.

${ }^{39}$ Por. ibidem, s. 29.
} 
$\operatorname{jan}^{40}$. Inne wytłumaczenie pochodzenia Saracenów wiąże się z niechlubnym określeniem ich przodka Ismaela. Piotr Pożeracz i Marsyliusz z Padwy powoływali się na Rdz 16,12, gdzie Ismael został przyrównany do dzikiego osła. Jego potomkowie odziedziczyli tę dziką naturę, co przejawia się w ich walce przeciw chrześcijanom i chrześcijańskim miejscom kultu. Poza tym uczeni uważali, że jeśli Ismael został zrodzony z niewolnej, to również Saraceni, którzy od niego pochodzą, są niewolnikami (tak też Franciszek de Zabarella) ${ }^{41}$.

Tego typu poglądy sprawiały, że Saracenów uznano za ludzi mniej wartościowych. Przekonania te utwierdzały ówcześnie szerzące się legendy, wzmacniane przez dawne przekazy na temat dalekich egzotycznych ludów ${ }^{42}$. $\mathrm{W}$ ten sposób tworzył się „stereotyp wroga nie mający z reguły wiele wspólnego z rzeczywistością" ${ }^{3}$.

Tworzenie takiego obrazu innowierców miało swoje konsekwencje. Wyprowadzanie pochodzenia Saracenów od niewolnicy Hagar lub od miasta Samarii miało na celu uzasadnić podporządkowanie niewiernych wiernym (tak uważał m.in. Wilhelm Durantis) ${ }^{44}$.

W podobny sposób wypowiadano się na temat żydów. Żydzi byli narodem wybranym, ale zawinili, przez co "stali się sługami wolnych wyznawców”. Według Hostiensisa chrzest sprawi, że staną się równi wyznawcom, a jako niżsi od wiernych żydzi nie mogą piastować urzędów, aby nie doszło do prześladowania wyznawców ${ }^{45}$. Oznacza to także, że tworzone prawo obowiązywać

\footnotetext{
${ }^{40}$ Por. ibidem, s. 32, 145.

${ }^{41}$ Por. ibidem, s. 38.

${ }^{42}$ Podobne przekazy były tworzone na temat żydów. Przekonują o tym liczne exempla powstałe w tamtym okresie. „Antyjudaizm więc istnieje, ale nie doprowadza do poważnych ekscesów, współistnienie różnych wyznań, mimo pojedynczych konfliktów jest możliwe i poszczególni wyznawcy judaizmu, a nawet całe grupy, przyjmują wiarę chrześcijańską dowodząc przez to jej przewagi i słuszności. Pełną i agresywną formę antyjudaizm uzyskuje - jeśli wierzyć exemplom - na przełomie XIII i XIV wieku. W tym okresie bierze się pod uwagę już nie indywidualne kontakty między przedstawicielami obu społeczności religijnych, lecz konfrontacje masowe. Wystarczy, że rozlegną się głosy obwiniające Żydów o zbezczeszczenie Boga i sakramentów, a natychmiast pojawiają się zaślepieni nienawiścią fanatyczni przywódcy i zaczynają zbierać się tłumy, gotowe burzyć domy wyznawców innej wiary i wlec ich na stos. Nietolerancja religijna, nieufność wobec ludzi, którzy trwają przy własnej wierze i obyczajach oraz prowadzą tryb życia wystarczająco odrębny, aby zrodzić podejrzenia i obawy, że są zagrożeniem dla chrześcijan - wszystko to tworzy korzystny grunt dla ekscesów i prześladowań. Prawa psychologii zbiorowej nabierają mocy prawa stanowionego, ujawniają się i niezwykle nasilają fobie masowe. Człowiek, który jeszcze wczoraj żył w zgodzie tuż obok innowiercy, staje się cząstką tłumu, burzącego jego dom i palącego go na stosie. Różnice religijne przekształcają się w fanatyczną nienawiść, która daje upust nagromadzonemu napięciu", por. A. Guriewicz, Kultura i społeczeństwo średniowiecznej Europy, s. 241.

${ }^{43}$ Por. L. Winowski, Innowiercy w poglądach uczonych, s. 23.

${ }^{44}$ Por. ibidem, s. 31.

${ }^{45}$ Por. ibidem, s. 141.
} 
miało nie tylko chrześcijan (społeczność wiernych), ale również tych, którzy żyli poza tą społecznością. Władza Kościoła rozszerzała się zatem na wszystkich, którzy zamieszkiwali chrześcijańską Europę. Oldradus de Ponte twierdził, że „wszystko poddane jest Chrystusowi, tak owce, jak bydło i polne zwierzęta”. Przez te rodzaje zwierząt Oldradus rozumiał poszczególne społeczności: wierni są owcami, natomiast Saraceni to bydło i polne zwierzęta ${ }^{46}$.

Zgodnie z tezą Oldarusa, jeśli wszystko poddane jest Chrystusowi, to papież powinien troszczyć się zarówno o wiernych, jak i niewiernych, co oznacza jednocześnie ingerowanie $\mathrm{w}$ ich $\dot{z} y$ cie $^{47}$. Papież posiadał władzę pełną i mógł reagować w sytuacji, gdy niewierni łamali prawo naturalne, czy też wówczas, gdy żydzi nie przestrzegali swojego prawa ${ }^{48}$. Wszelka inna ingerencja ze strony wiernych, która niosłaby ze sobą działanie na niekorzyść niewiernych (odbieranie im własności, odbieranie praw do zorganizowanego życia zbiorowego), była niedopuszczalna (tak Hostiensis, Wilhelm Durantis, Alvarus Pelagius) ${ }^{49}$. Tolerancją zostali obdarzeni jedynie ci niewierni, którzy uznawali władzę kościelną ${ }^{50}$.

Jednym z czynników sprzyjających kształtowaniu takiej świadomości człowieka średniowiecza były exempla. Można by je określić jako zabiegi retoryczne występujące $\mathrm{w}$ kaznodziejstwie wieków średnich ${ }^{51}$. Nieuwzględ-

${ }^{46}$ Por. ibidem, s. 30, 35-36, 37.

${ }^{47}$ Por. ibidem, s. 37; należy zauważyć, że mimo iż papież Bonifacy VIII w bulli Unam sanctam z 1302 r. wyłączył nieochrzczonych spod jurysdykcji kościelnej, to jednak ustawodawstwo oraz szkoły starały się wszelkie wątpliwości, jakie wiązały się z relacjami nieochrzczonych z Kościołem czy też $\mathrm{z}$ ochrzczonymi, prawnie regulować. Dotyczyło to $\mathrm{w}$ dużej mierze relacji ochrzczonych z żydami, których kontakty były oczywiste, por. W.M. Plöchl, Geschichte des Kirchenrechts, s. 65-66.

${ }^{48}$ Być może w tym miejscu warto przytoczyć słowa odnoszące się do różnicy w postrzeganiu świata przez kanonistów i moralistów. Zarówno jedni, jak i drudzy kształtowali prawo i jego wykładnię. „Znawcy prawa rzymskiego i kanonicznego zajmowali się w zasadzie stosunkami zewnętrznymi, a więc - jak to określano - «forum externum» w perspektywie interesujących ich systemów. Uwaga ta odnosi się głównie do kanonistów, ponieważ romaniści i tak tradycyjnie interesowali się głównie sferą zewnętrzną stosunków międzyludzkich. Inne stanowisko zajmowali moraliści. Ich interesowało przede wszystkim zachowanie się człowieka, i to nawet w sferze nieujawnionej na zewnątrz, przy czym układem odniesienia były tu zasady wiary i moralności chrześcijańskiej. Stąd też pytanie: czy «infidelitas» jest grzechem, stawiali przede wszystkim moraliści. Oczywiście pamiętać należy, że sposób zachowania się człowieka i zewnętrzny, i wewnętrzny łączy obszerna strefa graniczna oraz wzajemne związki przyczynowe i funkcyjne", por. L. Winowski, Innowiercy w poglądach uczonych, s. 25-26.

${ }^{49}$ Por. ibidem, s. 45.

${ }^{50}$ Por. ibidem, s. 147. Żydzi, choć według niektórych uczonych (np. Azo) nie błądzą tak samo jak heretycy, to jednak jedni i drudzy byli tak samo traktowani. „Żydzi mogą liczyć tylko na tolerancję", por. ibidem, s. 136.

${ }^{51}$ „Exemplum - krótka opowieść, przyjmowana za prawdziwą i przeznaczona do włączenia $\mathrm{w}$ treść przemowy, $\mathrm{z}$ reguły do kazania $\mathrm{w}$ celu podania słuchaczowi zbawiennej nauki", por. Cl. Bermond, J. Le Goff, J.-C. Schmitt, „L'exemplum” (Typologie des sources du Moyen Age occi- 


\begin{abstract}
nienie tego faktu doprowadza do ułomnej krytyki postawy ludzi Kościoła $\mathrm{w}$ tamtym okresie ${ }^{52}$.

Stereotypowe wyobrażenia o innowiercach przewijały się $\mathrm{w}$ oficjalnych dokumentach i powodowały wprowadzanie restrykcji, ale rzadko ściśle ich przestrzegano. Według L. Winowskiego, choć innowierców obarczano winą ignorancji, to jednak nie wiązały się z tym żadne praktyczne konsekwencje, gdyż prawo było egzekwowane w różnym stopniu ${ }^{53}$.
\end{abstract}

dental, Fasc. 40), Tumhout-Bruxelles 1982, s. 37-38, cyt. za: A. Guriewicz, Kultura i społeczeństwo średniowiecznej Europy, s. 17; „Exemplum stanowi swoisty «chronotyp» (termin M. Bachtina, oznaczający jedność przestrzenno-czasową utworu). W jakieś krótkiej chwili, nieskończenie odległej, legendarnej, albo odwrotnie - jak najbliższej momentowi kazania, w jakieś przestrzeni, znów albo nieokreślonej albo zupełnie konkretnej i znanej dobrze wszystkim, zachodzi niezwykłe, cudowne wydarzenie. To wydarzenie jest wynikiem zetknięcia się, spotkania dwóch światów: ziemskiego, gdzie występuje postać z exemplum - zakonnik, chłop, rycerz, mieszczanin, ktokolwiek bądź - ze światem pozaziemskim, niepodlegającym prawom czasu ziemskiego", por. A. Guriewicz, Kultura i społeczeństwo średniowiecznej Europy, s. 18; „Moralizatorski cel exemplów wymagał szczególnie krytycznego podejścia do człowieka, do społeczeństwa i różnych jego warstw. Kaznodzieja to przede wszystkim demaskator. Nie ma przywary i grzechu, których kazanie nie poddałoby analizie i nie potępiło. Liczne kompilacje exemplów zbudowane są według schematu siedmiu grzechów głównych, które rozpatrywane są po kolei w realnych, wziętych z życia sytuacjach, niezmiennie $\mathrm{z}$ wykorzystaniem interesującego, poglądowego materiału. Przed oczyma czytelnika przesuwają się przedstawiciele wszystkich warstw i grup społeczeństwa średniowiecznego, od władców i dostojników kościelnych do "prostaczków»: mieszkańcy miasta i wsi, klasztorów i zamków, mężczyźni i kobiety, starcy i dzieci, ubodzy i żebracy, lichwiarze i adwokaci, aktorzy, złodzieje, prostytutki, żydzi, heretycy... Kaznodzieja patrzy na jednostkę i społeczeństwo pod kątem grzechu - «sub specie peccati». Wszyscy jesteśmy winowajcami przed Bogiem i obok wspólnego dla wszystkich ludzi grzechu pierworodnego istnieją jeszcze specyficzne, że tak powiem, "profesjonalne» grzechy, znamienne dla ludzi różnych zawodów i statusów. Nikt nie ucieknie przed surowym sądem kaznodziei. Można w sposób uzasadniony stwierdzić, że żaden inny gatunek literatury średniowiecznej nie zawiera takiej dawki krytyki społecznej jak kazania, a zwłaszcza będące ich częścią exempla”, por. ibidem, s. 55. Podobna cudowność i łączność między światem ziemskim i nadprzyrodzonym obecna była w średniowiecznych legendach o świętych, por. J. de Voragine, Złota legenda. Wybór, Warszawa 2000.

${ }^{52}$ Exempla w zależności od miejsca powstawania różniły się między sobą. „(...) stosunek angielskich i francuskich autorów exemplów do Żydów był niejednoznaczny i podejmowali oni ten temat głównie w celu zademonstrowania potęgi chrześcijaństwa i jego zwycięstwa nad judaizmem. Nie zauważa się tutaj frontalnej wrogości między obu religiami i wspólnotami wyznaniowymi i ta postawa odzwierciedla rzeczywistą sytuację Żydów w społeczeństwie zachodnioeuropejskim tego okresu. Wzbudzali wprawdzie podejrzenia i czasami byli prześladowani, ale jednocześnie odnoszono się do nich $\mathrm{z}$ dużą tolerancją. Zupełnie inny obraz przedstawiony jest $\mathrm{w}$ exemplach kaznodziejów niemieckich. Wyraźniej niż u Francuzów czy Anglików przejawia się lęk przed «obcymi» czy to heretykami czy wyznawcami innej wiary. Antyjudaizm na gruncie niemieckim zapuścił już głębiej korzenie i przyniósł straszniejsze owoce niż w sąsiednich krajach Zachodu”, por. A. Guriewicz, Kultura i społeczeństwo średniowiecznej Europy, s. 237.

${ }^{53}$ Por. ibidem, s. 40. 


\section{Analiza C. 1-19, X, V, 6}

Odnośnie do sprawy żydów podejmowanej w Decretales Grzegorza IX należy zauważyć, że w Titulus VI Księgi V wszystkich innowierców przypisano do jednego paragrafu. Nie wyróżniono żydów chociażby ze względu na wspólną przeszłość z chrześcijanami.

Zawarte w Titulus VI Księgi V kanony zostaną pogrupowane w następujący sposób: prawa odnoszące się do kultu, prawa odnoszące się do ekonomii ${ }^{54}$, prawo ochrony żydów. Ponieważ temat artykułu obejmuje jedynie kwestię wyznawców judaizmu, w tym punkcie zostaną pominięte te kanony, które odnoszą się do Saracenów (VI i XII).

W kanonie XVII dokument akceptuje postanowienia Soboru Laterańskiego. Chodzi tu o Sobór Laterański IV z roku $1215^{55}$. Poza regulacjami dogmatycznymi, które miały znaczący wpływ na kształtowanie się doktryny Kościoła katolickiego, ojcowie soborowi podjęli również kwestie odnoszące się do żydów (w tym kanony 67-70 były niekorzystne dla żydów) ${ }^{56}$.

Prawa odnoszące się do kultu. Kwestię kultu podejmują trzy kanony: III, IV i VII. Kanony te sformułowane są negatywnie. Ograniczają one swobodę żydów w tworzeniu nowych miejsc kultu. Społeczność ta ma poprzestać na budynkach, które już istnieją, a prawo zezwalało jedynie na ich remont (kanony III i VII). Te zapisy prawne istniały już wcześniej, a Dekretales Grzeorza IX stanowią ich zebranie ${ }^{57}$.

\footnotetext{
${ }^{54}$ Przy czym termin „ekonomia” będzie tutaj rozumiany w sensie szerszym - jako zespół praw odnoszący się do współżycia między dwiema społecznościami: chrześcijan i żydów, zamieszkującymi jeden „dom” (wspólny obszar) i w naturalny sposób zmuszone są one do współdziałania, nie tylko w kwestii finansowej.

${ }^{55}$ Niemalże wszystkie postanowienia IV Soboru Laterańskiego weszły do Liber Extra, por. A. García y García, The Fourth Lateran Council and the Canonists, [w:] W. Hartmann, K. Pennington (red.), The History of Medieval Canon Law in the Classical Period, 1140-1234, s. 367.

${ }^{56}$ Por. M. Horoszewicz, Przez dwa millenia do rzymskiej Synagogi, s. 114-115; kanon 67: żydzi nie mogą wymuszać procentu, kanon 68: żydzi i muzułmanie muszą nosić odrębny strój i nie wyśmiewać chrześcijańskich obrzędów, kanon 69: żydzi nie mogą piastować publicznych urzędów, kanon 70: konwertyci z judaizmu na chrześcijaństwo nie mogą wracać do swoich dawnych rytów, por. A.J. Duggan, Conciliar Law 1123-1215: The Legislation of the Four Lateran Councils, [w:] W. Hartmann, K. Pennington (red.), The History of Medieval Canon Law in the Classical Period, 1140-1234, s. 354.

${ }^{57} \mathrm{~W}$ różny sposób respektowano te przepisy. W $1221 \mathrm{r}$. na polecenie papieża Honoriusza III nakazano zburzenie dwóch nowych synagog w Bourges. Nieraz jednak przepisu nie przestrzegano i synagogi mogły powstawać, jeśli były zachowane warunki: odległość między kościołem a synagogą musiała być właściwa, a także wysokość synagogi miała być odpowiednio niższa od wysokości kościoła, por. M. Horoszewicz, Przez dwa millenia do rzymskiej Synagogi, s. 138.
} 
Druga kwestia zawarta w kanonie IV odnosi się do obecności żydów w czasie wielkiego święta chrześcijan - Wielkiego Piątku. Ze świętami wielkanocnymi wiązały się także misteria paschalne jako publiczna forma przygotowania do przeżywania tych ważnych dni. Okres Triduum Paschalnego wzniecał antyżydowskie wystąpienia, ponieważ żydzi obarczani byli winą za śmierć Mesjasza. Nie mogli oni w tym dniu opuszczać swoich domów. $Z$ jednej strony jest to ograniczenie ich swobody, a $\mathrm{z}$ drugiej zakaz ten $\mathrm{w}$ jakieś mierze chronił żydów przed agresją ze strony chrześcijan ${ }^{58}$. Druga część kanonu XV także zaleca żydom, aby nie znajdowali się w Wielki Piątek na ulicach. Według M. Horoszewicza ma to zapewnić im bezpieczeństwo, jednakże dalsza część tego kanonu sugeruje, że obecność żydów w miejscach publicznych mogłaby być formą manifestacji znieważającą Boga.

Prawa odnoszące się do ekonomii. Tym prawom poświęcono najwięcej miejsca w analizowanym fragmencie źródła. Prawa regulujące współżycie między dwiema grupami: żydami i chrześcijanami, dotyczą głównie prac służebnych: czy to służby w postaci nianiek, czy na urzędzie. Podstawowa zasada, jaka kształtuje to prawo, brzmi następująco: chrześcijanie nie będą służyć żydom. Kanon VIII wyrażony jest w formie powinności: chrześcijanie nie powinni usługiwać żydom w ich domostwach. Nie jest to zatem całkowity zakaz, ale raczej zalecenie czy zobowiązanie do porzucenia służebnej postawy wobec żydów, której należy unikać.

Zalecenie to wzmacnia kanon I, według którego niewolnik we włościach żyda chcący przyjąć chrześcijaństwo może zostać wykupiony. Oznacza to, że nie jest konieczne porzucanie służby u żyda. Żydzi bowiem posiadali kolonów, którzy byli wyłączeni spod wspomnianego kanonu, ponieważ nie mili bezpośrednich kontaktów z innowiercami ${ }^{59}$. Jako chłopi przywiązani do ziemi mogli oni wykonywać pracę we włościach żydowskich, o czym zaświadcza kanon II. Służba żydom przejawiała się również w przejmowaniu roli mamek przez chrześcijanki. Według kanonu XIII kobiety chrześcijańskie nie powinny pracować w ten sposób ani pełnić posługi na rzecz żydów w ich domach.

Ten tryb powinności wyrażony we wspomnianym kanonie VIII został zaostrzony w kanonie V. Każdy chrześcijanin, który pełni służbę w domu żyda, Saracena czy poganina, zostanie obłożony karą ekskomuniki. Prace na rzecz innowierców kończyć by się miały wyłączeniem ze wspólnoty Kościoła.

\footnotetext{
${ }^{58}$ Por. ibidem, s. 115.

${ }^{59}$ Por. L. Winowski, Innowiercy w poglądach uczonych, s. 148.
} 
Służebność wobec żydów miała miejsce również wówczas, gdy żyd piastował ważny urząd $\mathrm{w}$ instytucjach publicznych. Także urząd świadka w sądowej sprawie wiernego był pojmowany w ten sposób (Hostiensis) ${ }^{60}$. Kanon XVIII przestrzega przed taką sytuacją. Jednakże ustępuje miejsca prawu stanowionemu przez władców świeckich. Jeśli świeccy władcy sprzyjają żydom i chcą ich mieć na ważnych stanowiskach, to wówczas prawo kanoniczne zaleca, aby chrześcijanin non suspectus zajął się ich zwerbowaniem. Żydzi bowiem zajmowali się sprawami finansowymi władców świeckich, stąd mogli liczyć na ich przychylnośćc ${ }^{1}$. Niemniej w kanonie XVI ustanowienie żyda przełożonym $\mathrm{w}$ publicznym urzędzie grozi chrześcijaninowi karą pozbawienia władzy.

W rozumieniu ówczesnych ludzi odrzucenie prawdy chrześcijańskiej przez żydów sprawiało, że zmianie uległa ich subiektywna kondycja bytowa. "Żydzi nie mogli uchodzić za ludzi w obiegowym rozumieniu”62. Wyznawcy Prawa mojżeszowego uznani zostali za zniewolony naród, a jako taki - nie mogli przewodzić wyzwolonym chrześcijanom ${ }^{63}$. Uważano, że śmierć Chrystusa wyzwoliła chrześcijan, a żydów zniewoliła. Stąd żydzi powinni przyjąć służebną postawę wobec goszczących ich chrześcijan ${ }^{64}$. W tym układzie "gospodarz" winien unikać wysługiwania się żydom.

Poza tym obostrzenia w zakresie wykonywania prac dla żydów miały na celu ograniczenie ich kontaktów z chrześcijanami. Rozporządzenia w tej materii pojawiły się już wcześniej. Na Soborze Laterańskim III w 1179 r. zakazano chrześcijanom pomieszkiwać wspólnie z żydami. Najprawdopodobniej ścisłe przestrzeganie tego postanowienia nie było powszechne od razu ${ }^{65}$, gdyż kontakty $\mathrm{z}$ innowiercami były dozwolone, o ile nie narażało się $\mathrm{w}$ ten sposób własnej wiary ${ }^{66}$.

\footnotetext{
${ }^{60}$ Por. ibidem, s. 142.

${ }^{61}$ Por. ibidem, s. 135.

${ }^{62}$ Por. M. Horoszewicz, Przez dwa millenia do rzymskiej Synagogi, s. 120.

${ }^{63}$ „Temat ich [żydów] zniewolenia pojawił się w liście papieskim z 1205 roku do króla Kastylii Alfonsa VIII, w którym upomniano monarchę, że mianując żydowskich urzędników, stawia służkę przed damę. W tym samym roku Innocenty III wezwał władców francuskich, żeby pohamowali «nieumiarkowanie» Żydów, «by ze szkodą dla szacunku należnego wierze katolickiej nie przyszło im do głowy podnosić karków, przygniecionych jarzmem wiecznego poddaństwa», por. Liber extra, 5, 6, 13, [w:] CICan, II, s. 776, cyt. za: J.H. Mundy, Europa średniowieczna 1150-1309, s. 75.

${ }^{64}$ Por. M. Horoszewicz, Przez dwa millenia do rzymskiej Synagogi, s. 140.

${ }^{65}$ Por. ibidem, s. 131.

${ }^{66}$ Według Hostiensisa unikać kontaktów z żydami mieli zwłaszcza ludzie prości, którzy w ten sposób mogą narazić swoją wiarę. Najprawdopodobniej trudno było prostemu ludowi wybronić się w dyskusjach teologicznych, por. L. Winowski, Innowiercy w poglądach uczonych, s. 135, 142; Podobnie argumentował Tomasz z Akwinu: jedynie ludzi z mocną wiarą mogą utrzymywać kon-
} 
Prawa odnoszące się do współżycia chrześcijan i żydów regulowały również sprawy kryminalne, jednakże tylko jednostronnie, tzn. prawo zawarte w Titulus VI reguluje jedynie te przypadki, w których stroną poszkodowaną był duchowny chrześcijański, a winnym był żyd. Według kanonu XIV akt agresji wobec duchownego kończył się dla żyda czasową karą, która mogła mieć też postać służby wykonywanej dla wspólnoty chrześcijan ${ }^{67}$.

Podobnie jak na terytoriach opanowanych przez Arabów, tak i w chrześcijańskiej części Europy żydzi mieli obowiązek noszenia odpowiedniego ubioru, który odróżniałby ich od chrześcijan. Potwierdza to kanon XV. Już na Soborze Laterańskim IV zapisano ten wymóg w kanonie $68^{68}$. W Titulus VI nie ma wyraźnie określonej postaci ubioru. Należy domniemywać, że w Decretales przejęto postanowienia soborowe (por. kanon XVII).

Zarówno ograniczenie praw żydów w pełnieniu funkcji publicznych, jak i rozporządzenie dotyczące ubioru miały charakter represyjny ${ }^{69}$. Żydzi próbowali odwoływać się od tych ustaleń czy to na podstawie kaucji, czy też zasług dla władców świeckich ${ }^{70}$.

Ograniczenia w dziedzinie handlu odniesione zostały w Titulus VI tylko do Saracenó $\mathrm{w}^{71}$. Natomiast prawnie wspierano misje prowadzone wśród pogan, gdyż mogły one wysłużyć przepowiadającemu odpusty (por. kanon X). Zgodnie z nomenklaturą Titulus VI misje te najwidoczniej nie obejmowały żydów.

takty z innowiercami, por. ibidem, s. 148; Augustinus Triumphus w rozmowach między ludźmi silnej wiary a innowiercami upatrywał możliwość nawrócenia tych drugich. Za niedopuszczalne uznawał jednak wspólne spożywanie posiłków z żydami, ponieważ według niego żydzi składali ofiary bożkom, por. ibidem, s. 154 .

${ }^{67}$ Hostiensis wspomina o karze grzywny i karze cielesnej, por. ibidem, s. 142.

68 „(...) na wszystkich ziemiach chrześcijańskich i po wszystkie czasy mają być publicznie odróżniani od reszty ludności jakością swej odzieży, zwłaszcza, że zostało to nałożone na nich również przez Mojżesza", por. M. Horoszewicz, Przez dwa millenia do rzymskiej Synagogi, s. 129. Nakaz wyróżniania się poprzez ubiór miał zmniejszyć ryzyko stosunków seksualnych między wiernymi a innowiercami. Postanowienie to podejmowane było przez sobory w Kościołach partykularnych i przez synody. W Anglii natomiast kwestię tę uregulowało rozporządzenie władcy. Szczegóły dotyczące wyglądu ubioru żydowskiego każde państwo ustaliło według własnego uznania, por. ibidem, s. 129-130; por. też Judenhut [online]. Wikipedia [dostęp: 2013-05-18]. Dostępny w Internecie: <http://de.wikipedia.org/wiki/Judenhut>; Gelber Ring; Viertes Laterankonzil [online]. Wikipedia [dostęp: 2013-05-18]. Dostępny w Internecie: <http://de.wikipedia.org/wiki/Viertes_ Laterankonzil>.

${ }^{69}$ Por. M. Horoszewicz, Przez dwa millenia do rzymskiej Synagogi, s. 115.

${ }^{70}$ Por. ibidem, s. 130.

${ }^{71}$ Handel z Saracenami prowadził do ekskomuniki i zredukowania statusu w hierarchii społecznej do najniższego szczebla (kanon VI). Handel i wszelkie inne relacje z Saracenami w czasie wojny z nimi powoduje ekskomunikę (kanon XII). Nie wolno było handlować winem, olejem ani jarzynami, chyba że celem transakcji było wykupienie jeńców chrześcijańskich, por. L. Winowski, Innowiercy w poglądach uczonych, s. 66 . 
Prawo chroniące żydów. W analizowanym fragmencie tekstu źródłowego obecny jest także kanon, który ochroną obejmuje społeczność żydowską i jej dobra. Kanon IX zabezpiecza nietykalność osobistą, gwarantuje swobodę w wyznawaniu wiary i nienaruszalność dóbr należących do wspólnoty żydowskiej.

Papieżom zależało na chrzcie żydów, ale pod warunkiem, że zostanie on przyjęty dobrowolnie. Następnie opiekowali się oni konwertytami, ponieważ z konwersją związane było pozbawienie praw do majątku. Żydzi w ramach swojej wspólnoty posiadali prawo wydziedziczania odszczepieńca ${ }^{72}$, a majątek mógł zostać przejęty przez władcę. Kanon V wykluczał ze społeczności Kościoła takich władców, którzy jeszcze przed konwersją żyda pozbawiali go majątku ${ }^{73}$. Należy jednak zaznaczyć, że według niektórych uczonych tamtego okresu (m.in. Hostiensis) prawo do posiadania mogli mieć jedynie ci innowiercy, którzy przyjmowali zwierzchnictwo Kościoła ${ }^{74}$.

Żydom przysługiwała również możliwość gromadzenia się na swoich uroczystościach i nikt nie mógł zakłócać ich nabożeństw. Nietykalnością objęte były także cmentarze żydowskie, które narażone były na kradzież. Złodzieje, kierowani chęcią zysku, byli skłonni dokonywać nawet ekshumacji. Bulle poświęcone kwestii żydowskiej potępiały odgrzebywanie zwłok na cmentarzach żydowskich, których celem było najprawdopodobniej spieniężenie znalezisk.

Kanon $\mathrm{V}$ analizowanego fragmentu dokumentu miał swoich poprzedników w postaci chociażby Constitutio pro Iudaeis z 1199 r. promulgowanej prze Innocentego III. Jej fragment brzmi następująco:

Aczkolwiek wiarołomstwo żydów jest wielorako godne potępienia, niemniej, ponieważ poprzez nich udowadnia się prawda naszej wiary, nie mogą być silniej ciemiężeni przez wiernych. (...) Ponadto żaden chrześcijanin niech się nie waży ranić ich albo zabijać bez wyroku. (...) Nakazujemy,

\footnotetext{
${ }_{72}$ Por. M. Horoszewicz, Przez dwa millenia do rzymskiej Synagogi, s. 137-138.

${ }^{73} \mathrm{~W}$ późniejszym okresie m.in. Jan XXII wydał dekret Dignum arbitrantes z 1320 r., w którym zawarł prawa chroniące żydów oraz zarządził, że konwertyci nie mogą być ograbieni ze swoich majątków i że powinni być chronieni przed prześladowaniami, por. W.M. Plöchl, Geschichte des Kirchenrechts, s. 67.

${ }^{74}$ „Jedyną koncesją, jakiej Hostiensis udziela innowiercom, jest możność posiadania własności i jurysdykcji, a nawet chrześcijańskich kolonów - poddanych. Chodzi tu jednak - podkreślmy to wyraźnie - o innowierców uznających zwierzchność Kościoła, a więc żyjących na ziemiach chrześcijańskich i z reguły podległych świeckim suwerenom. (...) Inni innowiercy, którzy nie uznają zwierzchności i władzy Kościoła, niegodni są własności i władztwa we wszelkich jego postaciach”, por. L. Winowski, Innowiercy w poglądach uczonych, s. 63-64.
} 
aby nikt nie ważył się naruszać ani pomniejszać cmentarza żydowskiego, ani w pogoni za pieniądzem wykopywać ludzkich zwłok ${ }^{75}$.

Wydawanie bulli zawierających formułę Sicut Iudaeis było swego rodzaju tradycją w okresie XII-XV w. Zapis prawa chroniącego żydów brzmiał mniej więcej tak samo. Ulegał on jednak pewnym modyfikacjom, zgodnie z aktualnymi potrzebami ${ }^{76}$. Do takich dokumentów można również zaliczyć potępienie przez Grzegorza IX w 1236 r. najazdów krzyżowców, którzy dokonali rzezi na bezbronnych żydowskich mieszkańcach Francji ${ }^{77}$.

Za Innocentego IV (1243-1254) przyznano innowiercom prawa do własności i własnych form życia zbiorowego. Według tego papieża prawo to przynależy do prawa naturalnego, które obejmuje wszystkie istoty rozumne, w tym także innowierców. Podlegają oni zatem prawu naturalnemu. Jeśli zaś innowiercy będą łamali prawo naturalne, spotkają ich za to właściwe konsekwencje $^{78}$.

\section{ZAKOŃCZENIE}

Przeprowadzona analiza C. 1-19, X, V, 6 pokazuje, że żydzi byli obiektem zainteresowania kanonistów. Kościół w XIII w. posiadał realną władzę polityczną. Mógł wpływać na postępowanie i decyzje władców świeckich, dlatego

\footnotetext{
${ }^{75}$ Por. M. Horoszewicz, Przez dwa millenia do rzymskiej Synagogi, s. 113.

${ }^{76}$ „Kalikst II [1119-1124] zagwarantował Żydom prawo do odrębnej wiary i posiadania własności, a potwierdzał je każdy kolejny papież. Wielokrotnie podejmowano próby walki z antyżydowskimi opowieściami o rytualnych mordach dokonywanych na chrześcijańskich chłopcach czynił to zwłaszcza Innocenty IV w 1247 i 1253 roku. W Rzymie, gdzie władcą był papież, każdy kolejny następca św. Piotra traktował wolność Żydów jak świętość”, por. J.H. Mundy, Europa średniowieczna 1150-1309, s. 74. Najprawdopodobniej od pontyfikatu Klemensa III (1187-1191) wydawanie tego typu bulli stało się regułą. Bulle te jednak oprócz praw przyznanych żydom zawierały również krytykę judaizmu, krytykę zatwardziałości jego wyznawców, por. M. Horoszewicz, Przez dwa millenia do rzymskiej Synagogi, s. 114. Wraz z bullami Sicut Iudaeis szły w parze bulle „antymordowe” z XIII w., które niestety nie wpłynęły znacząco na zatrzymanie szerzących się pomówień, por. ibidem, s. 127.

${ }^{77}$ Natomiast kościelne zgromadzenie w Tours w 1236 r. tak sformułowało zakaz i jednocześnie podało argument natury teologicznej, który go uzasadniał: „Stanowczo zabraniamy każdemu krzyżowcowi czy innemu chrześcijaninowi ośmielać się zabijać Żydów, chłostać ich, najeżdżać ich posiadłość. (...) Kościół toleruje Żydów, gdyż pragnie nie śmierci grzesznika, ale by wrócił i żył”, por. ibidem, s. 136. W 1233 r. Grzegorz IX wziął w obronę żydów przed mściwymi dłużnikami, aby zakończyć rozruchy we Francji, por. K.R. Stow, Papal and Royal Attitudes toward Jewish Lending in the Thirteenth Century, Association for Jewish Studies Review 6, 1981, s. 165; Ten sam papież w roku 1247 upomniał króla Navarry przed godzeniem w "dobre obyczaje” przez odmawianie spłaty pożyczek pobranych od żydów, por. ibidem, s. 169.

${ }^{78}$ Przykładem łamania prawa naturalnego było wielobóstwo, por. L. Winowski, Innowiercy w poglądach uczonych, s. 52 .
} 
też regulował różne kwestie, które, z dzisiejszego punktu widzenia, wykraczają poza jego kompetencje i cele, dla których został powołany.

Analizowany Titulus VI Księgi V Decretales Grzegorza IX umieszcza w jednej linii Saracenów, żydów i pogan. Cała ta grupa, określana mianem „innowierców”, ukazana została jako naród gorszy ze względu na wyznawaną wiarę, z którym trzeba z konieczności współżyć. Relacje między nimi a ludźmi przynależącymi do Kościoła nie mogły być swobodne, a raczej wymagały regulacji, których źródłem były zarówno poszczególne państwa Europy, jak i Kościół.

Relacje z Saracenami według C. 1-19, X, V, 6 regulowane są jedynie na płaszczyźnie ekonomicznej, a ściślej rzecz ujmując, handlu. Natomiast w odniesieniu do żydów przebadany dokument wkracza dużo głębiej. Sprawy handlu z przedstawicielami społeczności żydowskiej przeanalizowany fragment nie podejmuje, ale reguluje kwestie kultowe. Prawa dotyczące kultu miały charakter ambiwalentny: $\mathrm{z}$ jednej strony były one represyjne, $\mathrm{z}$ drugiej natomiast miały powstrzymać wystąpienia przeciw żydom i tym samym ich ochronić.

Są także takie regulacje, których jedynym celem wydaje się napiętnowanie żydów. Jedną $\mathrm{z}$ nich jest kwestia dotycząca ubioru. Na tej podstawie można stwierdzić, że prawo nie tylko regulowało, ale także mogło przyczynić się do umocnienia przekonań na temat wspólnoty żydowskiej. Utwierdzało wiarę w przesądy i w jakimś stopniu sankcjonowało upokorzenie żydów. Odrzucenie żydów i stawianie ich poza nawiasem społeczeństwa danego państwa potęgowały przeciwne żydom nastawienie ludzi przynależących do Kościoła. W ten sposób nieumyślnie Kościół „konstruował spiralę represyjną"79.

Badany fragment nie przedstawia naturalnie całego obrazu relacji kościelno-żydowskich regulowanych przez prawo kanoniczne. Wiele kwestii związanych z żydami znajduje się w innych miejscach Decretales (chociażby małżeństwa $\mathrm{z}$ innowiercami ${ }^{80}$ czy lichwa ${ }^{81}$ ). Należałoby zatem $\mathrm{w}$ dalszej kolejności przebadać również i te zapisy, ich charakter i siłę oddziaływania na społeczność żydowską.

\footnotetext{
${ }^{79}$ Por. M. Horoszewicz, Przez dwa millenia do rzymskiej Synagogi, s. 116.

${ }^{80}$ Por. C. 4, X, IV, 14; por. też J.A. Brundage, Intermarriage between Christians and Jews in Medieval Canon Law, Jewish History 3, 1, 1988, s. 25-40.

${ }^{81}$ Por. C. $12.18, \mathrm{X}, \mathrm{V}, 19$.
} 


\section{Kinga Anna Mrozek \\ THE ATTITUDE OF THE CATHOLIC CHURCH TOWARDS JEWS DURING THE PONTIFICATE OF GREGORY IX (1227-1241). ANALYSIS OF THE ISSUE IN THE LIGHT OF C. 1-19, X, V, 6}

\section{Summary}

The article addresses the relationship between the Catholic Church and Jews in the light of a passage in the first canon law, known as Decretales Gregorii IX (1234). The passage, found in Liber V (concerning crimes) of Titulus VI, consists of 19 canons. The article shows that Jews, Saracens and pagans were very much within the scope of interest of canonical jurists. In the orderly and hierarchical medieval Europe, the relationship between Christians and adherents of other denominations could not be left ungoverned but required legal regulation. With respect to relations with Jews, the said passage raises the issues of cult and everyday life. On the one hand, the canons it contains confirmed the curious notions about the Jewish community, but on the other indirectly protected Jews.

\section{Bibliografia}

Brundage J.A., Intermarriage between Christians and Jews in Medieval Canon Law, Jewish History 3, 1, 1988, s. 25-40.

Chazan R., The Condemnation of the Talmud Reconsidered (1239-1248), Proceedings of the American Academy for Jewish Research 55, 1988, s. 11-30.

Codex Iuris Canonici. Auctoritate Ioannis Pauli PP. II promulgatus. Kodeks Prawa Kanonicznego. Przekład polski zatwierdzony przez Konferencję Episkopatu, Poznań 1984.

Cohen J., Scholarship and Intolerance in the Medieval Academy: The Study and Evaluation of Judaism in European Christendom, The American Historical Review 91, 3, 1986, s. 592$-613$.

Dębiński A., Church and Roman Law, Lublin 2010.

Duggan A.J., Conciliar Law 1123-1215: The Legislation of the Four Lateran Councils, [w:] W. Hartmann, K. Pennington (red.), The History of Medieval Canon Law in the Classical Period, 1140-1234. From Gratian to the Decretals of Pope Gregory IX, Washington 2008, s. 318-366.

Flusser D., Chrześcijaństwo religią żydowską. Esseńczycy a chrześcijaństwo, Warszawa 2003.

Gabriel A.L., The Conflict Between the Chancellor and the University of Masters and Students at Paris During the Middle Ages, [w:] A. Zimmermann (red.), Die Auseinandersetzungen an der Pariser Universität im XIII. Jahrhundert, Berlin-New York 1976, s. 106-154.

García y García A., The Fourth Lateran Council and the Canonists, [w:] W. Hartmann, K. Pennington (red.), The History of Medieval Canon Law in the Classical Period, 1140-1234. From Gratian to the Decretals of Pope Gregory IX, Washington 2008, s. 367-378.

Grabois A., The Hebraica Veritas and Jewish-Christian Intellectual Relations in the Twelfth Century, Medieval Academy of America 50, 4, 1975, s. 613-634.

Guriewicz A., Kultura i społeczeństwo średniowiecznej Europy. Exempla XIII wieku, Warszawa 1997.

Hastings A. (red.), Historia chrześcijaństwa, Warszawa 2002.

Hemperek P., Góralski, W., Historia źródeł i nauki prawa kanonicznego, Lublin 1995. 
Horoszewicz M., Przez dwa millenia do rzymskiej Synagogi. Szkice o ewolucji postawy Kościoła katolickiego wobec Żydów i judaizmu, Warszawa 2001.

Johnson P., Historia Żydów, Kraków 2004.

Kootz W., Bamberg. Stadtführer durch die historische Altstadt mit Ausflügen in das sehenswerte Umland, Ubstadt-Weiher 2006.

Kuttner S., Raymond of Peñafort as editor: The "decretales" and "constitutiones" of Gregory IX, Bulletin of Medieval Canon Law 12, 1982, s. 65-80.

Le Goff J., Apogeum chrześcijaństwa ok. 1180-ok. 1330, Warszawa 2003.

Lewis C.S., Odrzucony obraz. Wprowadzenie do literatury średniowiecznej i renesansowej, Kraków 1995.

Mundy J.H., Europa średniowieczna 1150-1309, Warszawa 2001.

Paravicini Bagliani A., Kościół rzymski od Innocentego III do Grzegorza X, [w:] A. Vauchez (red.), Ekspansja Kościoła rzymskiego 1054-1274, Warszawa 2001, s. 441-482.

Pennington K., The Decretalists 1190-1234, [w:] W. Hartmann, K. Pennington (red.), The History of Medieval Canon Law in the Classical Period, 1140-1234. From Gratian to the Decretals of Pope Gregory IX, Washington 2008, s. 211-245.

Plöchl W.M., Geschichte des Kirchenrechts. Band II: Das Kirchenrecht der abendländischen Christenheit 1055 bis 1517, Wien-München 1962.

Poliakov L., Historia antysemityzmu. Epoka wiary, Kraków 2008.

Revel-Neher E., „By Means of Colors”: A Judeo-Christian Dialogue in Byzantine Iconography, [w:] R. Bonfil (red.), Jews in Byzantium. Dialectics of Minority and Majority Cultures, Leiden 2012, s. 501-534.

Ryś G., Inkwizycja, Kraków 1998.

Saltman A., Pseudo-Jerome in the Commentary of Andrew of St. Victor on Samuel, The Harvard Theological Review 67, 3, 1974, s. 195-253.

Stow K.R., Papal and Royal Attitudes toward Jewish Lending in the Thirteenth Century, Association for Jewish Studies Review 6, 1981, s. 161-184.

Vauchez A., Chrześcijanie wobec niechrześcijan, [w:] A. Vauchez (red.), Ekspansja Kościoła rzymskiego 1054-1274, Warszawa 2001, s. 580-606.

Voragine J. de, Złota legenda. Wybór, Warszawa 2000.

Winowski L., Innowiercy w poglądach uczonych zachodniego chrześcijaństwa XIII-XIV wieku, Wrocław 1985. 